\title{
The impact of food prices on the welfare of households in South Africa
}

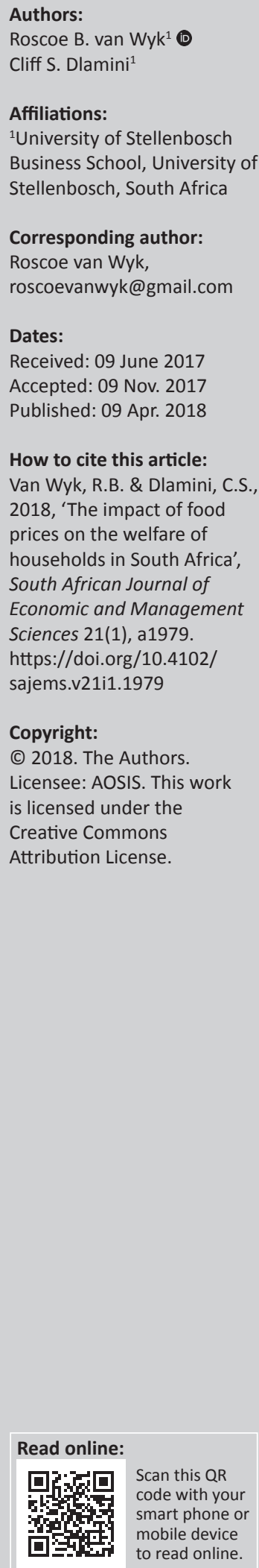

Background and setting: The global food price surge of 2006 to 2008 has negatively impacted South African households. Rising food prices adversely affect food security in South Africa. The ever-increasing prices for food commodities and lack of access to finance make it very difficult to strengthen food security amongst households in South Africa.

Aim: The aim of the study is to examine the impact of food prices on household welfare in South Africa. Additionally, the study attempts to analyse the short- and long-run relationship between food prices and household welfare in South Africa. This is done by determining how real household welfare responds and/or reacts whenever there is a shock in food prices and its fundamental determinants. Finally, the study attempts to distil recommendations toward a conceptual framework for the mitigation of the impact of high food prices on households in South Africa.

Method: The Vector Error Correction Modelling (VECM) technique is utilised to estimate a regression model.

Results: The results reveal that a $1 \%$ increase in food prices would reduce household welfare by $21.3 \%$. The study, therefore, confirms a negative correlation between food prices and welfare.

Conclusion: Short-run policy recommendations include: (1) subsidising staple food baskets for households in South Africa, (2) reducing prices of staple foods through the reduction of food tariffs and (3) reducing household expenditure on basic needs through subsidisation. These policy options could lessen the burden on households when there is a rise in the prices of staple food sources and therefore improve household welfare. Long-run policy recommendations include: (1) improving the unemployment rate in South Africa and (2) improving access to finance and credit for South African households. By addressing the rising unemployment rates and improving access to finance and credit in South Africa through job creation initiatives and improving micro-credit strategies, an environment can be created where households improve their disposable income.

\section{Introduction}

Rising food prices have an adverse effect on food security in South Africa. The literature thus suggests that food insecurity has been a major contributing factor to poverty in South Africa (Bonti-Ankomah 2001; Du Toit 2011; Van der Merwe 2011). The global and national food price surge of 2006 to 2008 had a negative impact on South African households. According to Maunder and Wiggins (2007), rising food prices came at a time when South Africa was experiencing a chronic food security crisis and the population was extremely vulnerable to food insecurity. The ever increasing prices of food commodities and the lack of access to finance make it very difficult to strengthen food security among households in South Africa.

Global trends suggest that food prices will increase year on year and thus affect the welfare of households. According to Attanasio et al. (2013:136), the considerable rise in global food prices over the last decade has concerning effects on the welfare of poorer households. The instability caused by price hikes is not a short-term problem and can have a lasting effect on poverty. Whether the consumers are poor or wealthy, the amount and quality of a consumer's food basket depend on its affordability, related to the consumer income. South African households depend on household income for consumption. According to Ssebagala (2016:1), rising living costs have caused South African households to focus more on utilisation of income for consumption expenditure instead of savings. Survey data have indicated that South African household consumption expenditure was recorded at an average of R16 122 per month (Statistics South Africa 2016:177). In view of the vast income inequality and limited food sources, South African 
households are unable to satisfy their unlimited want for food commodities from their limited financial resources. According to the World Bank (2010:1), rising food prices not only affect macroeconomic stability, but also the welfare of net buyers of food, which impact significantly on poorer households that use a larger proportion of income for food spending. The overall aim of the study is to establish the relationship between household welfare and food prices in South Africa and what measures can bring about sustainable food prices in South Africa. The primary objective of this study is to examine the impact of food prices on household welfare in South Africa covering the period of 1990 to 2015. The sub-objectives related to the primary objective are:

- To examine the relationship between food prices and household welfare in South Africa by determining how real household welfare responds/reacts whenever there is a shock in food prices and its fundamental determinants.

- To analyse the long-run relationship between food prices and household welfare in South Africa by determining how real household welfare responds/reacts whenever there is a shock in food prices and its fundamental determinants.

- To distil recommendations toward a conceptual framework for the mitigation of the impact of high food prices on households in South Africa.

\section{Literature review Market failure, household income and food prices}

Clarity on the causes of market failure by policymakers is important. Von Braun, Teklu and Webb (1993:76) stated that it was critical for the government to have an encompassing knowledge of the correlation between market and price behaviour in times of food crises. The government is the custodian of policymaking and implementation and thus needs to support remedial action in order to address the welfare impacts of rising food prices. Rocha (2006:5) argues that food insecurity should be included as a market failure, as it occurs when free markets are seen to be socially inefficient, when the market outcomes prove social benefits to be below the costs of society in respect of that outcome, or when benefits are not fully utilised via social resources. Hence, the market clearing variables do not maximise net social benefits (Kahn 1998:14). The presence of public goods and of negative externalities are the two most important causes of market failure in food security.

The relationship between relative and nominal prices forms the causal nature of changes in food prices and can be attributed to relative demand and supply conditions of both non-food and food commodities, resulting in a net increase in relative food prices (Belongia 1983:5). Rising food prices increase the risk faced by lower-income households and subsequently transfers real income from lower-income consumers (Newbery 1989). Rising food prices have an adverse effect on purchasing power. Poor households spend the majority of their household income on food, making food prices an important factor in the well-being of the poor
(Pinstrup-Andersen 1985:69). Hence, the changes in price of food commodities influence the ability of households to purchase food items (Jacobs 2009:413).

Rising food prices consist of a combination of variables influencing the welfare of the poor. Factors such as supply and demand, inventories, macroeconomic factors, exchange and interest rates, global economic activity, oil price volatility, global weather patterns, financial investment and agricultural policy all attribute to the volatility of food prices (Roache 2010).

Prices of food commodities continue to increase over time, leaving the poor vulnerable to food insecurity. A study done by the Food and Agriculture Organization of the United Nations in 2008 indicated that global nominal prices of all major food sources were at their highest levels in 50 years and continue to increase (Reyes et al. 2009:1). The poor are vulnerable to food price hikes, but policymakers can alleviate the burden suffered by the poor. Karfakis, Velazco and Covarrubias (2011:3) stated that approximately 70\% of the global poor population reside in rural areas and are dependent on agriculture for the possibility of improving their livelihoods, welfare and decreasing poverty rates.

South African urban households spend more toward food than do rural households. As demonstrated by BontiAnkomah (2001), rural households' food expenditure is approximately $23 \%$ of their total household spending at R588.00 whereas urban households spend approximately $15 \%$ of their household expenditure at R945.00. The difference between urban and rural food expenditure can be expected, as rural households may supplement spending toward food by subsistence farming or own food production.

\section{International evidence related to food prices}

There is diversity in the international empirical evidence that relates to food prices across the globe, with clear distinctions from country to country. In order to evaluate the impact of food prices on household welfare clearly and effectively in South Africa, it is crucial to understand how other countries have responded to the same impacts and the effectiveness of their reforms. The literature discusses the experience and reforms of three countries: Ghana, India and the USA. These countries differ in terms of income distribution, poverty levels and food security. However, each country has developed policy reforms and programmes to enhance food security and the welfare impact associated with food prices.

In 2008, Ghana imposed import duties on yellow corn, rice and wheat in an effort to lessen the burden on consumers from the adverse impacts of further rising food prices (Osei-Asare \& Eghan 2014:28). However, a study in Ghana suggested that the current policy reform of protecting domestic rice producers by means of import taxation did not contribute to the reduction of national poverty, as there is a tendency for rice growers in Ghana to remain poor 
(Minot \& Dewina 2013:v). It is challenging for Ghana's government to implement an effective policy due to tight market conditions for important agricultural commodities. For the government to make the correct policy decisions, an understanding of the causes of rising food prices, the implications of future rising food prices and how members of society are impacted by these effects is necessary (Organisation for Economic Co-operation and Development 2008:2). The understanding of these variables allows governments to improve decision-making which contributes to effective policy formation.

India has one of the highest rates of rising food prices among the developing economies. According to Bhattacharya and Gupta (2015:2), during the period of 2006 to 2013, India experienced food inflation at an average rate greater than $9 \%$, which was nearly double than the previous decade. Given that the rural poor households in India spend large portions of their total income toward food commodities, they are unable to divert additional resources to suppress the impact of rising food prices, thus strengthening food insecurity in the country. Three patterns can be distinguished in India's food price trends as compared to global food price trends. According to Dev (2009:3), when global food prices increased in 2005 to 2007, the first pattern of inflated food prices emerged. The rate at which food prices were inflated was a lot lower in India at the time. The second pattern saw India's food prices decrease during 2007-2008 when compared to 2006-2007, which is when global food prices significantly increased. The third pattern illustrated that global food prices declined at the end of 2008, but India's food prices escalated during this time, which was an indication that global food price increases had a marginal impact on India due to less exposure. The Indian government adopts a wide range of policy instruments to combat rising food prices. In 2007-2008, the Indian government arranged its intervention measures into two groups: first, economic policies, which included pricing policies, trade policies, stock management policy and public distribution; and second, social programmes. The social programme policy instruments included cash transfers, food for work, food rationing, school feeding schemes and rural employment schemes. The programmes and policies targeted trade and consumption, with little emphasis on a supply response. According to the World Bank (2010), high rising food prices turned the political economy of food into an important catalyst for short-term economic policy in South Asia and highlighted the transformation of food security into an important strategic tool for policymakers.

The USA is heavily reliant on food subsidies and tariffs for food security. Empirical evidence illustrates that more than $22 \%$ of children living in the USA live below the official poverty line and half will be on food stamps before they reach the age of 20 years (Kairos 2015). Food subsidies are included in price supports by the government, which guaranteed a price for a farmer's crops, whereby the state would purchase the excess crops. The USA Farm Bill of 2002 introduced payments for certain crops which are independent of price, also known as direct payments. The USA has experienced lower food tariffs on fruit and vegetable imports and also experienced higher tariffs from food-exporting countries around the world, resulting in the fact that export growth for the USA did not keep pace with import growth (Johnson 2014:5). The increase in imposed tariffs could have an effect on food prices, and thereby impact the food security and welfare of citizens of the USA.

\section{Food prices, household welfare and policy interventions}

Market information is a key factor when trying to correct price instability, especially in food markets. According to Keech, Munger and Simon (2012:8), without market data on the value of the damage caused by price hikes to markets, the state cannot determine its effects on households and thus lacks credible data and information. Literature detailing the causal relationship between increases in food prices and the adverse impact on households represents varying opinions. A number of empirical studies have indicated that there is a positive correlation between the increase in the price of food commodities and adverse welfare effects on the poor. However, there is also empirical literature that indicates that long-term price increases assist in agricultural development, which in turn impacts positively on employment and brings poverty relief. Jacobs (2009:413) suggests that the poorer households cope with rising food prices by reducing their purchases of food items and changing their consumption behaviour, which could change a household's status from one that is food secure to one that is not.

Literature also confirms that prices in agricultural food markets are much more inclined to volatility than in other industries. This is due to the supply of food commodities being inelastic in the short term, the demand for food being price inelastic and the unpredictability of food supply due to climate changes (Pettinger 2014). In 2008, South Africa had a projected total transfer cost, inclusive of agricultural subsidies, of between $2 \%$ and $4.5 \%$ (Demeke, Pangrazio \& Maetz 2009:21). This is a substantial proportion of gross domestic profit (GDP) allocated to assisting the burden suffered by the poor. However, the literature suggests that approximately $80 \%$ of South African rural households are unable to afford a basic nutritional basket of food, which would cost approximately R262.00 per month per person on average (Altman, Hart \& Jacobs 2009:351).

A study done by Aliber (2009:397), using Engel's Law, established that the total share of expenditure on food is higher the poorer the household is. In Mexico, a similar study indicated that changes in local food prices from the beginning of 2005 to the end of 2007 proposed a $1.7 \%$ rise in extreme poverty in rural households (Wood et al. 2011:78).

Recent studies have shown that policymakers are making strides with innovative mechanisms and legislation to accommodate rising food prices. Policymakers should implement demographical or geographical targeting in order 
to direct limited resources to households whose welfare is largely impacted by food price shocks (Rodriguez-Takeuchi \& Imai 2013:233). The current economic environment indicates sharp increases in food prices. Policymakers have attempted to lower food prices, while also limiting the signalling of higher global prices to domestic markets. Governments across the world have tried to formulate policies and legislation to overcome the adverse effects of food price hikes. Galtier (2009:2) states that since the 1980s, governments have tried to manage risks without affecting prices of food commodities, which affect a host of variables such as crop insurance and future markets, as well as influencing trade behaviour of food commodities. There is a desperate need for government intervention to curb seasonal food insecurity that affects the rural poor by deepening and widening social safety net programmes (Akter \& Basher 2014:161). Policymakers require strong legislation and policy to assist the poor in the face of the adverse effects of food price increases. According to Gouel (2013:1), the state must intervene when there is a lack of credibility in food market liberalisation due to a shortage of effective policy to protect the poor. The current policy barriers are the challenges regarding policy design that will build confidence in global markets and develop positive relationships between private and public agents.

\section{Methods Study design}

A deductive and/or inferential approach to research was used in this study, making use of a variety of literature concerning food security and insecurity aspects, especially regarding food price increases.

Further, the Vector Error Correction Modelling (VECM) technique was utilised to estimate a regression model. The VECM technique is known to be advantageous over the Ordinary Least Square and the Generalised Methods of Moments techniques, since it analyses both the short- and long-run relationship between variables. It is also well suited to handle the problem of endogeneity in the model.

\section{Data collection}

The study employed annual time series data derived from secondary sources such as the World Bank and the Organisation for Economic Co-operation and Development, covering the period 1990-2015. Since time series data is more concerned with ordering and listing of observations as the dependency, it offered this study several advantages over studies that use quarterly and monthly data. Due to the lack of welfare measurement in South Africa, the study employs household disposable income as a proxy. Furthermore, the study incorporates variables such as household final consumption expenditure, food prices, consumer price index and unemployment. All the variables in exception of food prices are collected in percentages and are not subjected to the natural logarithm since it would yield biased estimation.

\section{Data analysis}

The study employs the VECM approach quantified under the Vector Auto-Regressive (VAR) framework. This study adopted a quantitative nature since it produces descriptive data and, from an econometrics point of view, it is essential to utilise statistical packages such as the E-views 9 package which was utilised for the analysis.

The VECM technique incorporates procedures such as testing variables for an order of integration, using the Augmented Dickey Fuller (ADF) and Phillip Perron (PP) methods, determining the maximum lag length, and assessing the long-run association between variables using the Johansen cointegration technique in the estimation of both the short- and long-run relationships. Subsequent to the long- and short-run estimations, the study performed the stability and diagnostic test, using techniques such as the Jarque-Bera test of normality, the White heteroskedasticity test and the Breusch-Godfrey LM (Lagrange multiplier) test of serial correlation. Furthermore, the study performed the variance decomposition and General Impulsive Response Function to detect the behaviour of shocks in the variables employed toward household welfare in South Africa.

\section{Model specification}

This study develops a regression model as follows:

$H D I=f(U N, L N F P, H F C E, C P I)$

[Eqn 1]

Where:

- HDI - Household disposable income as a proxy of welfare

- UN - Unemployment

- LNFP - Food prices in a logarithm form

- HFCE - Household final consumption expenditure

- CPI - Consumer price index

The model can be transformed into a linear form as follows:

$$
H D I_{t}=\beta_{0}+\beta_{1} U N+\beta_{2} L N F P+\beta_{3} H F C E+\beta_{4} C P I+\mu_{t}
$$

Where:

- $\beta_{0}$-Constant

- $\beta_{1}, \beta_{2}, \beta_{3}, \beta_{4}-$ Coefficients

- $\mu_{t}-$ Error term

\section{Estimation techniques}

The study employed the VECM econometric approach to analyse the relationship between household welfare and food prices in South Africa. The VECM technique requires that the data be tested for stationarity or order of integration. The study adopted the ADF and PP test of unit roots.

The ADF test is applied using the following:

$\Delta Y_{t}=\beta_{0} X_{t}+\alpha Y_{t-1}+\mu_{t}$

[Eqn 3] 
Using the AR $(\rho)$ process, the hypothesis for the ADF test is quantified as follows:

$\mathbf{H}_{0}: \delta=1$ implies that the variable has unit root (non-stationary), and

$\mathbf{H}_{1}: \delta=<1$ implies that the variable does not have stationarity (stationary)

Once the stationarity is established using the ADF, the PP test of stationarity can be performed to check the robustness of ADF results. The test can be performed using the following equation:

$\Delta Y_{t}=\beta_{0} X_{t}+\alpha Y_{t-1}+\mu_{t}$

Table 1 demonstrates that when the ADF test is applied to variables at first difference, that none of the variables are stationary at $1 \%, 5 \%$ and $10 \%$ level of significance. As a result, the study fails to accept the null hypothesis of non-stationarity and concludes that variables are stationary and integrated at order I (see Eqn 1).

According to Philip-Perron, Table 2 tests the variables at first difference. All variables are stationary at $1 \%, 5 \%$ and $10 \%$ level of significance. The variables are tested at same models, which are Trend and Intercept, Intercept and None. Therefore, the study fails to accept the null hypothesis of non-stationarity and concludes that the variables are integrated at the same order of I (Eqn 1). Since there was evidence of stationarity in the variables, the study therefore proceeds estimating a nonspurious model of food prices and welfare impacts for South African households.

\section{Lag length selection results}

It is vitally important to conduct a lag length selection criterion to establish the number of lag to use. The lag selection can be done on the basis of Final Prediction Error

TABLE 1: Augmented Dickey Fuller test at first difference.

\begin{tabular}{|c|c|c|c|c|}
\hline Variables & Model & $t$-values(lags) & $5 \%$ critical value & Conclusion \\
\hline \multirow[t]{3}{*}{$\Delta \mathrm{HDI}$} & Intercept & $-4.549(5)$ & $-3.209 * * *$ & Stationary \\
\hline & Trend and intercept & $-4.757(5)$ & $-3.673 * * *$ & Stationary \\
\hline & None & $0.713(5)$ & $-1.160 * * *$ & Stationary \\
\hline \multirow[t]{3}{*}{$\Delta U N$} & Intercept & $-4.380(0)$ & $-2.991 * * *$ & Stationary \\
\hline & Trend and intercept & $-4.350(0)$ & $-3.612 * * *$ & Stationary \\
\hline & None & $-5.166(0)$ & $-1.953 * * *$ & Stationary \\
\hline \multirow[t]{3}{*}{$\triangle \mathrm{LNFP}$} & Intercept & $-6.863(0)$ & $-2.991 * * *$ & Stationary \\
\hline & Trend and intercept & $-6.913(0)$ & $-3.612 * * *$ & Stationary \\
\hline & None & $-1.357(2)$ & $-1.957 * * *$ & Stationary \\
\hline \multirow[t]{3}{*}{$\triangle \mathrm{HFCE}$} & Intercept & $-3.914(0)$ & $-2.991 * * *$ & Stationary \\
\hline & Trend and intercept & $-3.653(3)$ & $-3.644 * *$ & Stationary \\
\hline & None & $-3.986(0)$ & $-1.955 * * *$ & Stationary \\
\hline \multirow[t]{3}{*}{$\triangle \mathrm{GDP}$} & Intercept & $-5.349(0)$ & $-2.991 * * *$ & Stationary \\
\hline & Trend and intercept & $-5.445(0)$ & $-3.612 * * *$ & Stationary \\
\hline & None & $-5.449(0)$ & $-1.955 * * *$ & Stationary \\
\hline \multirow[t]{3}{*}{$\Delta \mathrm{CPI}$} & Intercept & $-4.820(3)$ & $-3.012 * * *$ & Stationary \\
\hline & Trend and intercept & $-5.216(3)$ & $-3.644 * * *$ & Stationary \\
\hline & None & $-4.421(3)$ & $-1.958 * * *$ & Stationary \\
\hline
\end{tabular}

Note: Level of significance $=*, 10 \% ; * *, 5 \% ; * * *, 1 \%$.

HDI, household disposable income; UN, unemployment; LNFP, food prices in a logarithm form; HFCE, household final consumption expenditure; GDP, gross domestic product; CPI consumer price index.
TABLE 2: Philip-Peron test of stationarity at first difference.

\begin{tabular}{|c|c|c|c|c|}
\hline Variables & Model & $\begin{array}{c}t \text {-values } \\
\text { (bandwidth) }\end{array}$ & $\begin{array}{l}5 \% \text { critical } \\
\text { value }\end{array}$ & Conclusion \\
\hline \multirow[t]{3}{*}{$\Delta \mathrm{HDI}$} & Intercept & $-38.045(8)$ & $-2.991 * * *$ & Stationary \\
\hline & Trend and intercept & $-37.413(8)$ & $-3.612 * * *$ & Stationary \\
\hline & None & $-2.501(3)$ & $-1.955 * * *$ & Stationary \\
\hline \multirow[t]{3}{*}{$\Delta U N$} & Intercept & $-4.416(3)$ & $-2.991 * * *$ & Stationary \\
\hline & Trend and intercept & $-6.949(3)$ & $-3.612 * * *$ & Stationary \\
\hline & None & $-4.526(3)$ & $-1.955 * * *$ & Stationary \\
\hline \multirow[t]{3}{*}{$\triangle$ LNFP } & Intercept & $-6.863(0)$ & $-2.991 * * *$ & Stationary \\
\hline & Trend and intercept & $-9.675(0)$ & $-3.612 * * *$ & Stationary \\
\hline & None & $-3.672(4)$ & $-1.955 * * *$ & Stationary \\
\hline \multirow[t]{3}{*}{$\triangle \mathrm{HFCE}$} & Intercept & $-3.870(4)$ & $-2.991 * * *$ & Stationary \\
\hline & Trend and intercept & $-3.841(3)$ & $-3.612 * *$ & Stationary \\
\hline & None & $-3.983(4)$ & $-1.955 * * *$ & Stationary \\
\hline \multirow[t]{3}{*}{$\Delta \mathrm{GDP}$} & Intercept & $-5.935(5)$ & $-2.991 * * *$ & Stationary \\
\hline & Trend and intercept & $-11.299(10)$ & $-3.612 * * *$ & Stationary \\
\hline & None & $-6.030(5)$ & $-1.955 * * *$ & Stationary \\
\hline \multirow[t]{3}{*}{$\Delta C P I$} & Intercept & $-4.643(7)$ & $-2.991 * * *$ & Stationary \\
\hline & Trend and intercept & $-5.570(10)$ & $-3.612 * * *$ & Stationary \\
\hline & None & -4.493 & $-1.955 * * *$ & Stationary \\
\hline
\end{tabular}

Note: Level of significance $=*, 10 \% ; * *, 5 \% ; * * *, 1 \%$.

$\mathrm{HDI}$, household disposable income; UN, unemployment; LNFP, food prices in a logarithm form; HFCE, household final consumption expenditure; GDP, gross domestic product; CPI, consumer price index.

TABLE 3: Selection of lag length used in the study at level form.

\begin{tabular}{lcccccc}
\hline Lag & LogL & LR & FPE & AIC & SC & HQ \\
\hline 0 & -166.990 & NA & 1.154 & 14.332 & 14.577 & 14.397 \\
1 & -74.389 & $138.900 *$ & 0.004 & 8.699 & $10.171 *$ & 9.089 \\
2 & -40.039 & 37.212 & $0.002 *$ & $7.919 *$ & 10.619 & $8.636 *$ \\
\hline
\end{tabular}

Lag, Past period variables/values; LogL, Log Linear; LR, Likelihood ratio; FPE, Final Prediction Error; AIC, Akaike Information Criteria; SC, Schwarz criterion; HQ, Hanna and Quinn.

*, Denotes the appropriate lag length for the model.

(FPE), Akaike Information Criteria (AIC), Schwartz Bayesian Information Criteria (SBIC), and Hanna and Quinn Information Criteria (HQIC).

The test was conducted and a lag of 2 was selected as reflected in Table 3. The lag of 2 was selected based on the Final Prediction Error (FPE), Akaike Information Criteria (AIC) and, Hanna and Quinn (HQ) results and it is used throughout the analysis of the study.

\section{Cointegration test results}

A cointegration test is essential in examining the long-run economic equilibrium relationship between variable $X$ and variable Y. Therefore this study employs the Johansen Maximum Likelihood Estimation process because of its ability to test for multiple cointegrating vectors. The procedure also permits for testing both restricted and unrestricted forms of cointegrating vectors and the speed of adjustment parameters.

According to Asteriou and Hall (2011), the Johansen approach is concerned with two assessments, namely the Trace test and the Maximum Eigenvalue. The tests represent the probability ratio test for the proposition that there are at most ' $r$ ' cointegrating vectors. The trace test and the Maximum Eigenvalue test can be conducted using the following formula:

$J_{\text {trace }}=-\mathrm{T} \sum_{i=r+1}^{n} \operatorname{In}(1-\lambda i)$

[Eqn 5] 
$J_{\max \text { Eigen }}=-\mathrm{TI} n(1-\lambda r+1)$

[Eqn 6]

Where $T$ is the sample size and $\lambda$ is the $i^{\text {th }}$ largest canonical correlation.

The Trace test results as reflected in Table 4 suggest that there is one cointegrating equation. The results obtained show that in the case of the trace test, the null hypothesis of no cointegrating equation is rejected since the test statistics of 96.844 are greater than the $5 \%$ critical value of 95.753 at none. This was a clear indication that there was one cointegrating equation at the $5 \%$ level.

The Maximum Eigenvalue test in Table 5 also indicated that at none, the Maximum Eigenvalue statistics of 46.589 are greater than the critical value of 40.078. As a result, the Maximum Eigenvalue also suggested one cointegrating equation at the $5 \%$ level. Since both trace test and Maximum Eigenvalue suggest one cointegrating equation, the study fails to accept the null hypothesis of no cointegration. This concludes that there is a long-run relationship among the variables.

\section{The Vector Error Correction Modelling estimation result}

The study estimated a VECM to capture both the long- and the short-run effect between the variables.

The relationship reflected in Table 6 can be presented in a linear form as follows: $H D I_{t}=-197.761-0.054 U N_{t}-$ 21.318LNFP t $_{t}-1.481$ HFCE $_{t}+0.516 G D P_{t}-0.389$ CPI $_{t}^{+} \varepsilon_{t^{*}}$

The long-run relationship between the variables as explained in the above equation suggested that there was a negative long-run insignificant relationship between UN and HDI in South Africa. The study also proved a long-run negative relationship of LNFP, HFCE and CPI toward HDI and a long-run positive relationship between GDP and HDI. All explanatory variables in exception of UN and GDP were statistically significant in explaining the dependent variable since they have absolutely had a $t$-value greater than two.

The implication of the negative relationship between UN and HDI was that a $1 \%$ increase in UN would deteriorate HDI by $0.05 \%$ in South Africa. Furthermore, a 1\% increase in LNFP, HFCE and CPI would also reduce HDI by $21.3 \%, 1.5 \%$ and $0.4 \%$, respectively. GDP is found to be positively correlated with HDI since it is observed that $1 \%$ increase would improve the HDI by $0.5 \%$.

As indicated in Table 7 below, the coefficient of the depended variable is -0.071 and is statistically significant with a $t$-value of -2.045 . This suggests that about $7 \%$ of the variation in the real GDP from its equilibrium level is correlated within a year. Based on this result, the adjustment of the GDP to restore long-run equilibrium is weak at $7 \%$ per annum.
TABLE 4: Trace test results.

\begin{tabular}{llll}
\hline Hypothesized no. of CE(s) & Trace statistic & $\mathbf{0 . 0 5}$ Critical value & Prob.\$ \\
\hline None† & 96.844 & 95.753 & 0.042 \\
At most 1 & 50.254 & 69.818 & 0.626 \\
At most 2 & 23.425 & 47.856 & 0.953 \\
At most 3 & 9.225 & 29.797 & 0.989 \\
At most 4 & 3.876 & 15.494 & 0.913 \\
At most 5 & 0.683 & 3.841 & 0.408 \\
\hline
\end{tabular}

$\mathrm{CE}$, cointegrating equation; Prob., Probability.

Note: Trace test indicates 1 cointegrating equation(s) at the 0.05 level.

$\dagger$, rejection of the hypothesis at the 0.05 level; $\ddagger$, no rejection of hypothesis at the 0.05 level.

TABLE 5: Maximum Eigenvalue results.

\begin{tabular}{llll}
\hline $\begin{array}{l}\text { Hypothesized } \\
\text { no. of CE(s) }\end{array}$ & Max-Eigen statistic & $\mathbf{0 . 0 5}$ Critical value & Prob. * \\
\hline None $\dagger$ & 46.589 & 40.077 & 0.0081 \\
At most 1 & 26.829 & 33.876 & 0.272 \\
At most 2 & 14.199 & 27.584 & 0.808 \\
At most 3 & 5.348 & 21.131 & 0.992 \\
At most 4 & 3.193 & 14.264 & 0.933 \\
At most 5 & 0.683 & 3.841 & 0.408 \\
\hline
\end{tabular}

$\mathrm{CE}$, cointegrating equation; Prob., Probability.

Note: Max-Eigen test indicates 1 cointegrating equation(s) at the 0.05 level.

$\dagger$, rejection of the hypothesis at the 0.05 level; $\$$, no rejection of hypothesis at the 0.05 level.

TABLE 6: Long-run regression results: Household disposable income.

\begin{tabular}{llll}
\hline Variable(s) & Coefficient & Standard errors & $t$-statistics \\
\hline UN (-1) & -0.054 & 0.046 & -1.164 \\
LNFP(-1) & -21.318 & 0.515 & 41.371 \\
HFCE (-1) & -1.481 & 0.134 & 11.046 \\
GDP (-1) & 0.516 & 0.089 & -1.748 \\
CPI(-1) & -0.398 & 0.069 & 5.728 \\
\hline
\end{tabular}

UN, unemployment; LNFP, food prices in a logarithm form; HFCE, household final consumption expenditure; GDP, gross domestic product; $\mathrm{CPI}$, consumer price index.

TABLE 7: Short-run regression results.

\begin{tabular}{llll}
\hline Variable(s) & Coefficient & Standard errors & $t$-statistics \\
\hline CointEq1 & -0.071 & 0.067 & -2.054 \\
D(HDI[-1]) & -0.551 & 0.031 & -3.722 \\
D(UN[-1]) & -0.012 & 0.031 & -0.386 \\
D(LNFP[-1]) & 2.467 & 2.095 & 1.177 \\
D(HFCE [-1]) & 0.016 & 0.055 & 0.304 \\
D(GDP[-1]) & 0.089 & 0.033 & 2.708 \\
D(CPI[-1]) & 0.077 & 0.029 & 2.639
\end{tabular}

$\mathrm{HDI}$, household disposable income; UN, unemployment; LNFP, food prices in a logarithm form; HFCE, household final consumption expenditure; GDP, gross domestic product; CPI, consumer price index.

\section{General impulsive response function}

It is traditional to interpret the VARs using the Impulsive Response Function (IRFs). According to Sims (1980), the IRFs are useful in the VAR framework since they allow for tracing out the time path of the numerous shocks on the variables. Plotting the IRF is a useful technique for visual representation of the behaviour of the series in response to the various shocks. Mujuta (2013) pointed out that impulse responses trace out the response of the present and forthcoming value of one VAR error, assuming that this error returns to zero following periods and that all other errors are contemporaries to zero. In the estimation, IRFs are used to interpret results because it is very difficult to use individual coefficients, as was stated by Bjonness (2012).

The study applied the General Impulsive Response Function to trace the magnitude of one-time shock to one of the 
innovations on the present and forthcoming values of the endogenous variables. The General Impulsive Response Function over the 10 years for the VECM estimation is shown in Appendix 1. Results in Appendix 1 suggest that HDI responds positively to the impulse coming from itself, LNFP and GDP throughout the period of 10 years. Furthermore, it responds negatively to impulse coming from CPI starting from period 3 until period 10. The impulse coming from $\mathrm{UN}$, HFCE were fluctuating between negative and positive toward HDI. The study therefore concludes that household disposable income responds positively to shocks coming from food prices.

\section{Food prices affecting household welfare}

The results of the VECM estimation reveal that a short- and long-run relationship exists between food prices and household welfare in South Africa. Similar findings by Galtier (2009) reveal that rising food prices have short- and long-run effects on household welfare. The results of this article reveal that rising food prices negatively affect the welfare of households in South Africa and, similarly, a study completed by Mackinnon (1998) acknowledges the decline in household welfare that occurred in Ethiopia during 1984 and 1985 due to excessive increases in food prices.

A similar proxy used in a study conducted in India by De Janvry and Sadoulet (2010), who utilised changes in real income as the first estimate to changes in welfare of households. This indicated a money-metric loss in welfare, caused by changes in income and consumption prices. The study confirmed similar findings similar to those of this article, where rising food prices negatively affected household welfare (De Janvry \& Sadoulet 2010). The study by Schreitter (2016) suggested that heterogeneity tests had indicated that the correlation between food prices and household welfare was even lower for poor households. The theory and analysis were strengthened by a study undertaken Alem and Soderbom (2012:146) who also conducted research in Ethiopia related to the impact of rising food prices on household welfare and suggested that welfare of the poor living in Ethiopia was sensitive to food price changes. The VECM estimation results were in agreement with the both studies done by Schreitter (2016) and Alem and Soderbom (2012), namely, that poorer households were adversely affected by rising food prices.

The study also revealed a strong positive correlation between food prices and household welfare and further, that there was a strong negative impact on household welfare when food prices increased. A similar outcome was obtained in a study completed by Adom (2013), which concentrated on the microeconomic impacts of rising food prices and assessed the potential welfare effects of increasing food prices on households residing in Ghana.

\section{Key findings}

The study adopted the Vector Error Correction Modelling procedures to answer the question whether food prices had an impact on household welfare in South Africa and analysed the behaviour of variables such as unemployment, household final consumption expenditure, food prices and the CPI toward household welfare.

The cointegration analysis confirmed a long-run relationship among variables. A significant negative relationship between food prices and household welfare was discovered, which implied that an increase in food prices would result in household welfare reduction in South Africa. The short-run model estimated revealed convergence toward equilibrium in the long-run, although the adjustment was weak at $7 \%$ per annum. The results confirmed that the model did not suffer from heteroskedasticity, serial correlation and normality challenges. The polynomial test confirmed the stability of the model since all AR polynomial had roots with a modulus which were $<1$ and they lay within the unit circle. Based on the above results, this study concludes that food prices are detrimental to household welfare in South Africa. These results are believed to be efficient and consistent, based on the diagnostic and stability test undertaken.

\section{Conclusion}

The welfare impacts on South African households have largely been negative when there were increases in food prices. The study revealed that a short- and long-run relationship exists between food prices and household welfare in South Africa through determining the response of real household welfare when a shock in food prices occurred. Confirmation of a largely negative correlation between food prices and household welfare was revealed, which found that household welfare declined when there was a rise in food prices in South Africa. The study implies that an increase in food prices results in a reduction of household welfare in South Africa and the results revealed that household welfare responded to shocks in food prices.

The study, therefore, confirms a negative correlation between food prices and welfare in the short-run. The results of the study revealed that household welfare responded to shocks in food prices in the long run and therefore confirms a negative correlation between food prices and welfare. The study, based on results of the model, confirmed that food prices impacted on household welfare in South Africa and the results are credible, efficient and consistent due to the diagnostic and stability tests that were performed. The policy options in the short run to address the impact of food prices on household welfare in South Africa could include the following:

- Subsidising staple food baskets for households in South Africa;

- Reducing prices of staple foods with the reduction of staple food tariffs;

- Reducing household expenditure on basic needs through subsidisation.

Long-run impacts on household welfare can be stabilised through the following policy mechanisms:

- Improving the unemployment rate in South Africa;

- Improving access to finance and credit. 
The successful implementation of recommendations by the South African government to implement policy options, such as food subsidies and tariffs for staple food sources, will provide South African households with the following:

- Sustainable food prices for South African households

- Improvement of household welfare by reducing staple food prices;

- Reduction of total household expenditure.

However, through fiscal constraint, the government is hesitant to engage in projects that will take up large amounts of fiscal resources. Agriculture and food security are, however, government priorities and are prioritised within the National Development Plan. Hence the recommendations of this research provide a provisional strategy toward creating an environment for sustainable food prices in South Africa. Further research on creating sustainable food prices in South Africa is necessary to reduce the implications on household welfare in South Africa, especially the poor.

\section{Acknowledgements Competing interests}

The author declares that he has no financial or personal relationships which may have inappropriately influenced him in writing this article.

\section{Authors' contributions}

R.B.v.W. is the corresponding author and C.S.D. reviewed and supervised the first author in writing this article.

\section{References}

Adom, K.P., 2013, The impact of rising food prices on household welfare in Ghana Department of Economics, University of Ghana, Accra.

Akter, S. \& Basher, S.A., 2014, 'The impacts of food price and income shocks on household food security and economic well-being: Evidence from rural Bangladesh', Journal for Global Environmental Change 25(1), 150-162. https:// doi.org/10.1016/j.gloenvcha.2014.02.003

Alem, Y. \& Soderbom, M., 2012, 'Household-Level consumption in Urban Ethiopia: The effects of a large food price shock', Journal for World Development 40(1), 146-162. https://doi.org/10.1016/j.worlddev.2011.04.020

Aliber, M., 2009, 'Exploring statistics South Africa's national household surveys as sources of information about household-level food security', Agrekon Journal 48(4), 384-409. https://doi.org/10.1080/03031853.2009.9523833

Altman, M., Hart, T.G.B. \& Jacobs, P.T., 2009, 'Household food security status in South Africa', Agrekon Journal 48(4), 345-361. https://doi.org/10.1080/03031853.2009. 9523831

Asteriou, D. \& Hall, S.G., 2011, Applied econometrics, Palgrave Macmillan, New York.

Attanasio, O., Di Maro, V., Lechene, V. \& Phillips, D., 2013, 'Welfare consequences of food prices increases: Evidence from rural Mexico', Journal of Development Economics 104(1), 136-151. https://doi.org/10.1016/j.jdeveco.2013.03.009

Belongia, M.T., 1983, Why do food prices increase? viewed 06 September 2014, from https://research.stlouisfed.org/publications/review/83/04/Food_Apr1983.pdf

Bhattacharya, R. \& Gupta, A.S., 2015, Food inflation in India: Causes and consequences, National Institute of Public Finance and Policy, New Delhi.

Bjonness, L.C., 2012, Uncertainty and the transmission of fiscal policy: The case of omitted Variables Bias, MA thesis, University of Oslo, Oslo, Sweden.

Bonti-Ankomah, S., 2001, Addressing food insecurity in South Africa, The National Institute for Economic Policy, Pretoria.

De Janvry, A. \& Sadoulet, E., 2010, The impact of rising food prices on household welfare in India, University of California, Berkeley, CA.

Demeke, M., Pangrazio, G. \& Maetz, M., 2009, Country responses to the food security crisis: Nature and preliminary implications of the policies pursued, Agricultural Policy Support Service, Food and Agriculture Organization of the United Nations, Rome.
Dev, S.M., 2009, Rising food prices and financial crisis in India: Impact on women and children and ways for tackling the problem, UNICEF Social Policy Programme, Government of India, Delhi.

Du Toit, D.C., 2011, Food security, directorate economic services, production economics unit, Department of Agriculture, Forestry and Fisheries, Pretoria.

Galtier, F., 2009, The need for public intervention to stabilize prices, viewed 04 June 2014 from http://www.fondation-farm.org/zoe/doc/conference09_resumeoutilsdegestion eng.pdf

Gouel, C., 2013, Food price volatility and domestic stabilization policies in developing countries, viewed 05 September 2014, from http://www.nber.org/chapters/ c12816.pdf

Jacobs, P.T., 2009, 'The status of household food security targets in South Africa', Agrekon Journal 48(4), 410-433. https://doi.org/10.1080/03031853.2009.9523834

Johnson, R.,2014, The U.S. trade situation for fruit and vegetable products, viewed 06 August 2016, from https://www.fas.org/sgp/crs/misc/RL34468.pdf

Kahn, J.R., 1998, The economic approach to environmental and natural resources, The Dryden Press, New York.

Kairos, 2015, Current US Poverty Statistics, viewed 03 June 2016, from http:// kairoscenter.org/wp-content/uploads/2015/02/Poverty-Fact-Sheet-Feb-2015final.pdf

Karfakis, P., Velazco, E.M. \& Covarrubias, K., 2011, Impact of increasing prices of agricultural commodities on poverty, viewed 06 September 2014, from http:// www.fao.org/3/a-am320e.pdf

Keech, W.R., Munger, M.C. \& Simon, C., 2012, Market failure and government failure, Public Choice World Congress, Miami, FL.

Mackinnon, J., 1998, Food storage, multiple equilibria and instability: Why stable markets may become unstable during food crises, Centre for the Study of African Economies, Oxford.

Maunder, N. \& Wiggins, S., 2007, Food security in South Africa: A review of lessons learnt on responses to chronic and transitory hunger and vulnerability, Natural Resource Perspective, London.

Minot, N. \& Dewina, R., 2013, Impact of food price changes on household welfare in Ghana, International Food Policy Research Institute (IFPRI), Washington, DC.

Mujuta, S.C., 2013, The effectiveness of fiscal deficits in stimulating economic growth, MA thesis, University of the Western Cape, Cape Town.

Newbery, D., 1989, Missing markets: Consequences and remedies, Clarendon Press, Gloucestershire.

Organisation for Economic Co-operation and Development, 2008, Rising food prices: Causes and consequences, viewed 18 June 2016, from http://www.oecd.org/ trade/agricultural-trade/40847088.pdf

Osei-Asare, Y.B. \& Eghan, M., 2014, 'Food price inflation and consumer welfare in Ghana', International Journal of Food and Agricultural Economics 1(1), 27-39.

Pettinger, T., 2014, Problems of agriculture - Market failure, viewed 07 September 2014, from http://www.economicshelp.org/blog/4977/economics/problems-ofagriculture-market-failure/

Pinstrup-Andersen, P., 1985, 'Food prices and the poor in developing countries', European Review of Agricultural Economics 12(1/2), 69-81. https://doi org/10.1093/erae/12.1-2.69

Reyes, C.M., Sobrevinas, A.B., Bancolita, J. \& De Jesus, J., 2009, Analysis of the impact of changes in the prices of rice and fuel on poverty in the Philippines, viewed 04 August 2014, from http://dirp3.pids.gov.ph/ris/dps/pidsdps0907.pdf

Roache, S.K., 2010, What explains the rise in food price volatility?, Working Paper, International Monetary Fund, Research Department, Washington, DC.

Rocha, C., 2006, Food insecurity as market failure: A contribution from economics, School of Nutrition and Centre for Studies in Food Security, Ryerson University, Ontario.

Rodriguez-Takeuchi, L. \& Imai, K.S., 2013, 'Food price surges and poverty in urban Columbia: New evidence from household survey data', Journal of Food Policy 43(1), 227-236. https://doi.org/10.1016/j.foodpol.2013.09.017

Schreitter, V., 2016, Measuring the welfare impacts of food price increases: Evidence from rural Ethiopia, viewed 10 January 2017, from https://editorialexpress.com/ cgi-bin/conference/download.cgi?db_name=CSAE2016\&paper_id=855.

Sims, C.A., 1980, 'Macroeconomics and reality', Econometrica Journal 48(1), 1-48. https://doi.org/10.2307/1912017

Ssebagala, R., 2016, What matters more for South African households' debt repayment difficulties, Center for Social Science Research, University of Cape Town, Cape Town.

Statistics South Africa, 2016, General household survey, 2015, Statistical Release, Pretoria.

Van der Merwe, C., 2011, Key challenges for ensuring food security in South Africa's inner cities, Africa Institute of South Africa, Pretoria.

Von Braun, J., Teklu, T. \& Webb, P., 1993, 'Famine as the outcome of political production and market failures', IDS Bulletin 24(4), 73-79. https://doi. org/10.1111/j.1759-5436.1993.mp24004008.

Wood, B.D.K., Nelson, C.H. \& Nogueira, L., 2011, 'Poverty effects of food price escalation: The importance of substitution effects in Mexican households', Journa of Food Policy 37(1), 77-85. https://doi.org/10.1016/j.foodpol.2011.11.005

World Bank, 2010, Food price increases in South Asia, National responses and regional dimensions, The International Bank for Reconstruction and Development, Washington, DC 


\section{Appendix 1}

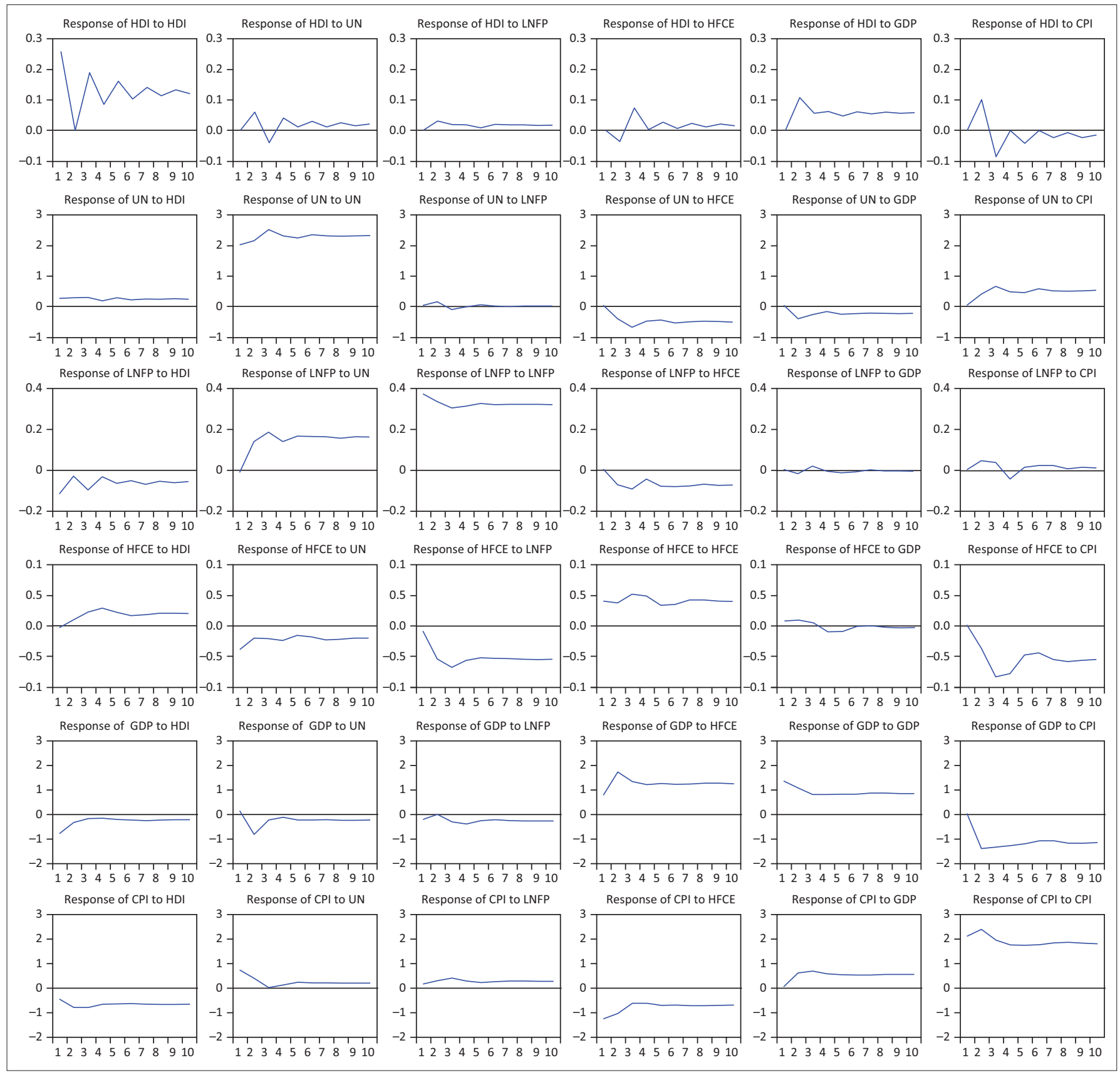

FIGURE 1-A1: General Impulsive Response Function. 